\title{
ESTIMATION OF HUMAN HEALTH RISK FROM POLYCHLORINATED BIPHENYLS THROUGH CONSUMPTION OF FISH FROM BLACK SEA, BULGARIA
}

\author{
Stanislava Katelieva Georgieva \\ Department of Chemistry, Faculty of Pharmacy, Medical University of Varna
}

\begin{abstract}
INTRODUCTION: Fish are reliable indicators of the bioaccumulation of persistent toxic substances in the environment, and they are usually used to estimate contaminant exposure risks to humans. The present study evaluates the human daily intake of polychlorinated biphenyls (PCBs) through consumption of fish from the Black Sea, Bulgaria. The health risks were assessed using a risk quotient (RQ) of the fish consumption as the ratio of daily fish exposure level in relation to oral reference dose.
\end{abstract}

MATERIALS AND METHODS: PCBs were determined in the muscle tissue of four fish species widely consumed by the population of Bulgaria: goby (Neogobius cephalargoides), sprat (Sprattus sprattus), horse mackerel (Trachurus Mediterraneus ponticus) and shad (Alosa pontica pontica). Samples were collected from the Bulgarian Black Sea coast in the period 2007 - 2011. The indicator and dioxin-like PCBs were determined by capillary gas chromatography system with mass spectrometry detection.

RESULTS: The sum of the six indicator PCBs ranged from 7.2 to $27.3 \mathrm{ng} / \mathrm{g}$ ww (in goby and shad, respectively). The EDI of I-PCBs in fish from Black Sea was calculated to be between 1.36 and $5.14 \mathrm{ng} / \mathrm{kg}$ bw day through consumption of goby and shad, respectively.

DISCUSSION: RQ values calculated were much lower than one, suggesting that consumption of the fish species would not pose any non-cancer risk. Dioxin - like PCBs were used in order to estimate the toxicity potential (TEQs) of PCB exposure. WHO-TEQs of the 6 "dioxin-like" PCB congeners ranged from $0.03 \mathrm{pg}$ TEQ/g ww (goby) to $0.28 \mathrm{pg} \mathrm{TEQ/g} \mathrm{ww} \mathrm{(shad)} \mathrm{and} \mathrm{did} \mathrm{not} \mathrm{exceed} \mathrm{the} \mathrm{limit} \mathrm{of} 3 \mathrm{pg} \mathrm{TEQ} / \mathrm{g}$ ww, according to European Commission.

CONCLUSION: The estimated intake levels of dioxin-like PCBs in this study were several orders lower than their respective TDI for adults. The dietary intake of polychlorinated biphenyls through marine fish for the Bulgarian consumer does not pose a health risk.

Keywords: PCBs, fish, dietary intake, Black Sea, Bulgaria

Address for correspondence:

Stanislava Georgieva 55 Marin Drinov Str. Medical University of Varna 9002 Varna, Bulgaria

e-mail: stanislavavn@mail.bg

Received: May 16, 2016

Accepted: December 20, 2016

\section{INTRODUCTION}

Persistent organic pollutants (POPs) like polychlorinated biphenyls (PCBs) are chemicals of global concern due to their persistence in the environment, ability of biomagnification and bioaccumulation in ecosystems. PCBs are highly lipophilic compounds and they are rapidly accumulated in living organisms (1). These very persistent compounds have the potential to affect the physiological functions of wildlife 
(2). Many authors have revealed that high fish and seafood consumption increases the risk of PCB contamination of the human body $(1,3)$. Humans are exposed to these chemicals in different ways: mainly through the food they eat, but also through the air they breathe, in the outdoors and indoors (4). Although PCBs are regulated in the European Union, they are still present in our food at low levels (3).

According to their toxicological properties, PCBs are usually divided into two groups: dioxinlike PCBs (dl-PCBs) and non-dioxin-like PCBs (ndlPCBs). The dioxin-like PCBs (dl-PCB) show a similar toxicity as polychlorinated dibenzodioxins and polychlorinated furans. The dl-PCBs are used in order to estimate the toxicity potential of PCB exposure as toxic equivalency (TEQ). TEQ is defined by the sum of the concentration of each dl-PCB congener in a mixture multiplied by its toxic equivalency factors (TEF), developed by the World Health Organization (WHO-TEF) (5). The sum of the six PCBs (IUPAC No. 28, 52, 101, 138, 153 and 180) comprises about half of the amount of total non-dioxin-like PCBs present in feed and food (6). They are called indicator PCBs (I-PCBs) for evaluating the risk to human health (7).

Several methods have been proposed for the assessment of the potential human health risks from these chemicals exposure. Current non-cancer risk assessment methods are usually based on the use of the risk quotient (RQ). RQ is a ratio between the estimated dose of a contaminant and the reference dose below which there will not be any appreciable risk (8). If RQ exceeds unity, there may be concern for potential health effects. Another approach for estimating exposure and risks by dietary intake of toxic substances is the TEQ methodology, use of toxic equivalency factors (TEFs) $(9,10)$. In most cases, dietary intake has been the major source of total human exposure to PCBs $(11,12)$. It has been reported that meat, dairy products and fish, make up more than $90 \%$ of the intake of PCBs for the general population $(13,14,15)$.

The aims of this study were:

$\diamond$ to estimate daily intake of $\mathrm{PCBs}$ through consumption of marine fish from the Black Sea

$\diamond$ to assess the human health risk due to polychlorinated biphenyls

\section{MATERIALS AND METHODS}

\section{Sampling}

Samples were caught by local professional fishermen by net from 2007 to 2011 . The sampling strategy allows covering the entire Bulgarian Black Sea coast and includes three important fishing regions: North (near cape Kaliakra, Krapec and Balchik), Varna Bay and South (Bourgas, Nessebar). The fish species were selected according to their importance to human consumption in Bulgaria: goby (Neogobius cephalargoides), sprat (Sprattus sprattus sulinus), horse mackerel (Trachurus Mediterraneus ponticus), and shad (Alosa pontica pontica.)

\section{Analytical Method}

The method used for the preparation of the samples, clean-up and quantitative determinations of PCBs in fish samples has been previously described in detail (16). Briefly, twenty grams of homogenized fish tissue were extracted with hexane/dichloromethane in Soxhlet Extractor. The extract was cleaned-up on a glass column packed with 2 g neutral silica, $4 \mathrm{~g}$ acid silica and $2 \mathrm{~g}$ neutral silica (Merck KGaA, Darmstadt, Germany). The eluates were concentrated to near dryness and reconstituted in $0.5 \mathrm{ml}$ hexane. One micro liter of purified extract was injected into GC/MS.

Gas chromatographic analyses of PCBs were carried out by GC FOCUS (Thermo Electron Corporation, Austin, Texas, USA) using POLARIS Q Ion Trap mass spectrometer. Splitless injections of $1 \mu \mathrm{l}$ were performed using a TR-5MS capillary column (Bellefonte, PA, USA) coated with cross-linked 5\% phenyl methyl siloxane with a length of $30 \mathrm{~m}, 0.25$ $\mathrm{mm}$ ID and a film thickness of $0.25 \mu \mathrm{m}$. Helium was applied as carrier gas at a flow of $1 \mathrm{ml} / \mathrm{min}$.

Pure reference standard solutions (PCB Mix 20 - Dr. Ehrenstorfer Laboratory, Augsburg, Germany), were used for instrument calibration, recovery determination and quantification of compounds. Measured compounds were: the six indicator PCBs (IPCBs IUPAC No. 28, 52, 101, 138, 153 and 180) and six dioxin-like PCBs (non-ortho PCBs 77, 126, 169 and mono-ortho PCBs 105, 118, 156). Each sample was analyzed three times and an average of the results obtained was taken. 


\section{Quality Control}

The quality control was performed by regular analysis of procedural blanks and certified reference material BB350 (PCBs in fish oil) - Institute for Reference Materials and Measurements, European Commission. Recovery of PCBs from certified reference material varied in the range $85-109 \%$ for individual congeners.

\section{Statistical Analysis}

The statistical analysis of the data was based on the comparison of average values by a t-test and a significance level of $\mathrm{p}<0.05$ was used. When the $\mathrm{p}$-value was lower than 0.05 , it was considered statistically significant. All statistical tests were performed using SPSS 16 software. For the purpose of statistical analysis, concentrations of contaminants reported as "not detected" were assigned as the detection limit. The data used in the present study were based on the mean concentrations of the target contaminants in the fish species.

\section{Dietary Intake Estimation}

Human exposure assessment of PCBs through oral ingestion is generally estimated using daily intake of the contaminant. The estimated total daily intake (EDI) of the contaminants in a given fish species was calculated as follows (17):

$$
\mathrm{EDI}=\mathrm{C} \mathrm{x} \text { Intake } / \mathrm{BW}
$$

where EDI is the estimated daily intake (ng/kg body wt./day), $\mathrm{C}$ is the average concentration of measured PCBs (ng/g wet weight), Intake is the daily food consumption of fish (13.2 g/ day for Bulgarian standard adult (18) and BW is the average consumer body weight (70 kg for adult men).

\section{Risk Assessment}

The potential risks of non-carcinogenic effects are evaluated by the risk assessment index known as the risk quotient (RQ). RQ is defined as the ratio of daily fish exposure level (EDI) in relation to reference dose (RfD) considering non-carcinogenic effects of the contaminants. The RQ was calculated as follows $(8,17)$ :

$$
\mathrm{RQ}=\mathrm{EDI} / \mathrm{RfD}
$$

where EDI is the estimated daily intake $(\mathrm{ng} / \mathrm{kg}$ body wt./day); and RfD is the reference dose (ng/kg day). The RfD applied in this study was $20 \mathrm{ng} / \mathrm{kg}$ day (8).

\section{Toxic Equivalency (TEQ) Methodology}

Toxic equivalency factors (TEFs) are being developed to assess the potency of polyhalogenated aromatic hydrocarbons, including dioxin-like polychlorinated biphenyls (dl-PCBs), polychlorinated dibenzo-pdioxins (PCDDs) and dibenzofurans (PCDFs). Toxic equivalency factors (TEFs) are essentially weighting factors by which the toxicity of a congener is compared to that of 2,3,7,8-tetrachlorodibenzo-pdioxin (TCDD) - Table 1 (5).

In our study the concentrations of individual dl-PCB congeners are multiplied by their TEFs and the results summed to give a toxicity value expressed in TCDD toxic equivalents (TEQs) through the following equation:

$$
\text { dl-PCB TEQ }=\sum \text { dl-PCBi } x \text { TEFi }
$$

Table 1. Toxic equivalency factors (TEFs) for dioxin-like PCBs (5)

PCB UPAC No. TEF -WHO 2005

non-ortho $P C B s$

PCB 77

0.0001

PCB 126

0.1

PCB 169

0.03

mono-ortho PCBs

PCB 105

0.00003

PCB 118

0.00003

PCB 156

0.00003

\section{RESULTS}

The concentration levels of individual PCBs congeners were described in our previous study (16). The PCBs load of each fish was estimated on the basis of the six indicator PCBs congeners (UPAC No.28, 
$52,101,138,153$ and 180) recommended by the European Union for assessing the pollution by PCBs (7).

The lipid content, mean levels of total indicator PCB congeners in investigated fish species from the Black Sea coast of Bulgaria, estimated daily intake (EDI) and risk quotient (RQ) are shown in Table 2 . The lipid percentage ranged from $1.7 \%$ in goby to $22.6 \%$ in shad.

\section{DISCUSSION}

\section{Indicator PCBs Levels}

The mean levels of I-PCBs ranged between 7.22 ng/g ww (goby) and $27.26 \mathrm{ng} / \mathrm{g}$ ww (shad), calculated as the sum of 6 Indicator PCB congeners. Our previous studies showed that the most abundant PCB congeners in fish species were the indicator PCBs constituting more than $80 \%$ of the total amount of PCBs

Table 2. Levels of total indicator PCBs ( $\mathrm{ng} / \mathrm{g}$ wet weight, mean and standard deviation) determined in fish collected from the Black Sea, estimated daily intake (EDI) and risk quotient (RQ).

\begin{tabular}{|c|c|c|c|c|c|c|}
\hline Species & $\mathrm{n}$ & $\begin{array}{l}\text { Lipids, } \\
\%\end{array}$ & $\begin{array}{c}\text { Sum I-PCBs, } \\
n g / g w w\end{array}$ & $\begin{array}{c}\text { EDI, } \\
n g / \mathrm{kg} / b w\end{array}$ & $\begin{array}{c}\text { RfD, } \\
n g / k g / \text { day (USEPA) }\end{array}$ & RQ \\
\hline goby & 18 & $1.7 \pm 0.6$ & $7.22 \pm 4.37$ & $1.36 \pm 0.82$ & 20 & 0.07 \\
\hline sprat & 11 & $5.8 \pm 1.8$ & $10.57 \pm 2.45$ & $1.99 \pm 0.46$ & 20 & 0.10 \\
\hline horse mackerel & 18 & $11.7 \pm 2.6$ & $10.96 \pm 4.56$ & $2.05 \pm 0.93$ & 20 & 0.10 \\
\hline shad & 12 & $22.6 \pm 6.2$ & $27.26 \pm 6.04$ & $5.14 \pm 1.14$ & 20 & 0.26 \\
\hline
\end{tabular}

The concentration levels of the individual six dioxin-like PCBs (dl-PCBs) congeners (non-ortho PCBs 77, 126, 169 and mono-ortho PCBs 105, 118, 156) were measured in our previous study (16). In Table 3 the data was summarized and the sum of the six dl-PCBs congeners (mean values) was presented for the fish species investigated. In order to compare the results obtained to permissible limits set forth in the EU Council Regulation, the TEQ values and estimated daily intake (EDI) of dl-PCBs were calculated for each fish species and mean values are shown in Table 3.
(19). The European Union has recommended a maximum level of $75 \mathrm{ng} / \mathrm{g}$ wet weight, calculated as the sum of the six I-PCBs in the muscle meat of fish (7). Our results for the sum of I-PCBs in all fish species did not exceed this limit.

\section{Estimated Daily Intake (EDI) of I-PCBs}

Fish and seafood accounts for a small portion of human diet, but it has been proven to be one of the major routes of human exposure to organic contaminants (12). The consumption of contaminated fat-food can be a potential risk for the consumer. To comprehensively evaluate risk exposure, the mean EDIs for these harmful chemicals in each fish species were calculated. On the basis of the measured concentrations in the fish samples, the daily dietary in-

Table 3. Sum of six dl-PCBs (ng/g ww mean and standard deviation), determined in fish, TEQs (pg TEQ/g ww) and EDI (pg TEQs/kg bw)

\begin{tabular}{l|cccc} 
Species & $\begin{array}{c}\text { Sum dl-PCBs, } \\
\text { ng/g ww }\end{array}$ & $\begin{array}{c}\text { pg TEQ-WHO 2005 } \\
\text { /g ww }\end{array}$ & $\begin{array}{c}\text { EDI, } \\
\text { pg TEQ / kg bw }\end{array}$ & WHO 2000 (25) \\
goby & $1.44 \pm 0.36$ & $0.03 \pm 0.01$ & 0.006 & \\
sprat & $2.54 \pm 0.82$ & $0.08 \pm 0.02$ & 0.015 & $1-4 \mathrm{pg} \mathrm{TEQ/kg} \mathrm{bw}$ \\
horse mackerel & $2.02 \pm 1.84$ & $0.06 \pm 0.02$ & 0.011 & 0.053 \\
shad & $9.08 \pm 2.68$ & $0.28 \pm 0.08$ & & \\
\hline \hline
\end{tabular}

TDI - tolerable daily intake 
take of PCBs was calculated. The estimated daily intake of the PCBs in fish species studied are shown in Table 2 . The estimated daily intake was calculated on the basis of a fish consumption rate of $13.2 \mathrm{~g} /$ day (18) for adults with body weight of $70 \mathrm{~kg}$, on the mean exposure level. The EDI of I-PCBs in fish from Black Sea was calculated between 1.36 and $5.14 \mathrm{ng} / \mathrm{kg}$ bw day through consumption of goby and shad, respectively. Overall, the EDIs of these POPs via fish consumption for adults in the present study were lower than those reported in most previous studies $(6,20)$.

\section{Human health risk assessment}

The non-carcinogenic effect of a toxic substance is considered to be acute exposure effects over brief periods of time, such as hours or days. However, this does not necessarily result in an acute response. The RfD is an estimate of daily exposure in humans that is likely to be without an appreciable risk of deleterious effects during a lifetime (17). The average consumption together with the measured concentration of the contaminant are used to calculate the risk quotient RQ. RfD values adopted in this study are the criteria of the USEPA (Environment Agency of the United States) (8). If the RQ value is less than 1, no obvious health risks due to the intake or uptake of contaminants via fish consumption would be experienced. Conversely, an exposed population of concern will experience health risks if the fish consumption rate is equal to or greater than the RfD value (17). The RQ values ranged from 0.07 to 0.26 for goby and shad, respectively (Table 2). All the RQ values were much lower than 1, suggesting that consumption of the fish species would not pose any non-cancer risk.

\section{Dioxin - Like PCBs Levels}

TEQ values were calculated by multiplying the individual dl-PCBs congener levels measured in each sample with its toxic equivalency factors (TEF), established by the World Health Organization (WHOTEF) (5). As it is shown in Table 3, the lowest total TEQ values, expressed as pg TEQ/g ww, were established in goby samples (mean 0.03 pg TEQ/g ww) and the highest results were observed in shad samples (mean $0.28 \mathrm{pg}$ TEQ/g ww).

The comparison of our results for TEQ values in fish with those in the literature showed lower levels than the TEQs in sardine from the Spanish Atlantic southwest coast ( 0.75 pg TEQ /g ww)
(21) and lower than those in salmon from the Baltic Sea (12.6 pg TEQ /g ww) (22). The total WHOTEQ values measured in fish from the southern Baltic Sea varied from $3.4 \mathrm{pg} / \mathrm{g}$ fresh weight to $15.2 \mathrm{pg} / \mathrm{g}$ fresh weight (23). In a market study on the dietary intake of PCDD/Fs and PCBs performed in Finland, Kiviranta et al. (24) measured the concentrations of these pollutants in fish samples. The sum of PCDD/ Fs was $2.0 \mathrm{pg}$ WHO-TEQ/g ww, and that of PCBs $1.5 \mathrm{pg}$ WHO-TEQ/g ww. The European Union has set a limit of $3.0 \mathrm{pg}$ TEQ/g wet weight in the muscle meat of fish for the sum of dioxin-like PCBs (7). In our study TEQs of the six dl-PCBs for all investigated fish species did not exceed this limit.

\section{Estimated Daily Intake (EDI) of dl-PCBs}

The World Health Organization recommended the TEF approach, applying the recently established WHO TEFs (5), for estimating the daily intake for humans of dl-PCBs (Table 3) in units of TCDD equivalents for comparison to the Tolerable Daily Intake (TDI). WHO has set a TDI for the sum of PCDD/F-TEQ and dl-PCB-TEQ of 1-4 pg TEQ kg/ body weight (25), which is comparable with a tolerable weekly intake of $14 \mathrm{pg}$ TEQ/kg body weight as fixed by the European Union Scientific Committee on Food (26).

In this study, estimated daily intake of dl-PCBs from Bulgarian food consumption data was from 0.006 to $0.053 \mathrm{pg}$ TEQs kg/ body weight/ day (for goby and shad, respectively). Both of these values were lower than the TDI of 1 to $4 \mathrm{pg}$ TEQs $\mathrm{kg} /$ body weight/ day recommended by WHO (25). These estimations were also lower than those reported in Spain - mean dietary intake of dl-PCBs from fish and seafood was estimated at $15.18 \mathrm{pg}$ WHO-TEQ/ day in 2010 (27). Bordajandi et al. (28) analyzed a great variety of food purchased across the city of Huelva (Spain) - total daily intake of PCDD/Fs and PCBs was estimated to be $2.63 \mathrm{pg} \mathrm{WHO}-\mathrm{TEQ} / \mathrm{kg}$ body weight. The intake of PCDD/Fs plus dioxin-like PCBs through fish and other seafood in various cities of Catalonia, Spain was estimated to be $38.0 \mathrm{pg}$ WHO-TEQ/day (29).

\section{CONCLUSION}

The PCB levels found in this study are generally lower than those reported from the other regions. Our results for the sum of I-PCBs in fish species in- 
vestigated ranged between $7.2 \mathrm{ng} / \mathrm{g}$ ww (goby) and $27.3 \mathrm{ng} / \mathrm{g}$ ww (shad) and did not exceed the maximum level of $75 \mathrm{ng} / \mathrm{g}$ ww. WHO-TEQs were found in the range from $0.03 \mathrm{pg}$ TEQ/g ww for goby to 0.28 pg TEQ/g ww for shad and did not exceed the limit of $3.0 \mathrm{pg}$ WHO-TEQ/g ww for sum of six dioxin-like PCBs. The contamination of the fish species investigated with PCBs appears to be relatively low compared to other European studies. The lower observed levels of PCB in fish tissues than from fish tissues of other aquatic ecosystems was potentially due to the absence of PCB manufacturing in Bulgaria. The estimated intake levels of dioxin-like PCBs in this study were several orders lower than their respective TDI for adults. We can conclude that the dietary intake of polychlorinated biphenyls through marine fish for the adult Bulgarian consumer does not seem to pose a health risk.

\section{REFERENCES}

1. Masmoudi W, Romdhane MS, Kherriji S, El Cafsi M. Polychlorinated biphenyl residues in the golden grey mullet (Liza aurata) from Tunis Bay, Mediterranean Sea (Tunisia). Food Chem. 2007;105:72-76.

2. Langer P, Kocan A, Tajtakova M, Petrik J, Chovancova J, Drobna B, et al. Possible effects of polychlorinated biphenyls and organochlorinated pesticides on the thyroid after long-term exposure to heavy environmental pollution. J. of Occup. \& Environ. Med. 2003;45:526- 532.

3. Voorspoels S, Covaci A, Neels H. Dietary PCB intake in Belgium, Environ Toxicol and Pharmacol. 2008;25:179-182.

4. UNEP, Human exposure to POPs across the globe: POPs levels and human health implications. 2013. Available from: http://www.unep.org/chemicalsandwaste/portals/9/POPs/docs/UNEP-POPSCOP.6-INF-33.English.pdf

5. Van den Berg M, Birnbaum LS, Denison M, De Vito M, Farland W, Feeley M, et al. The 2005 World Health Organization reevaluation of human and Mammalian toxic equivalency factors for dioxins and dioxin-like compounds. Toxicol Sci. 2006;93(2):223-241.

6. EFSA (European Food Safety Authority). Results of the monitoring of non dioxin-like PCBs in food and feed. EFSA Journal. 2010;8:35.

7. European Commission. Commission Regulation (EU) No 1259/2011 of 2 December 2011 amend- ing regulation (EC) no. 1881/2006 as regards maximum levels for dioxins, dioxin-like PCBs and non dioxin-like PCBs in foodstuffs. Off J of EU. 2011;L320:18-23.

8. USEPA (United States Environmental Protection Agency). Guidance for Assessing Chemical Contaminant Data for Use in Fish Advisories. EPA 823B-00-008, 2000;2, Available from: http://water.epa. gov/ scitech/ swguidance/fishshellfish/techguidance/risk/volume2index.cfm $>$.

9. Storelli MM \& Marcotrigiano GO. Occurrence and accumulation of organochlorine contaminants in swordfish from Mediterranean Sea: A case study. Chemosphere. 2006;62:375-80.

10. Storelli MM. Potential human health risks from metals $(\mathrm{Hg}, \mathrm{Cd}$, and $\mathrm{Pb}$ ) and polychlorinated biphenyls (PCBs) via seafood consumption: Estimation of target hazard quotients (THQs) and toxic equivalents (TEQs). Food and Chem Toxicol. 2008;46:2782-2788.

11. European Commission. Assessment of dietary intake of dioxins and related PCBs by the population of EU Member States. 2000; Available from: http:// www.ec.europa.eu/dgs/health_consumer/library/ pub/pub08_en.pdf.

12. Smith AG \& Gangoli S. Organochlorine chemicals in seafood: occurrence and health concerns. Food and Chem Toxicol. 2002;40:767-79.

13. Schecter A, Cramer P, Boggess K, Stanley J. \& Olson JR. Levels of dioxins, dibenzofurans, PCB and DDE congeners in pooled food samples collected in 1995 at supermarkets across the United States. Chemosphere. 1997;34:1437-47.

14. Domingo JL, Bocio A, Falcó G, Llobet JM. Exposure to PBDEs and PCDEs associated with the consumption of edible marine species. Environ. Sci. Technol. 2006;40:4394-4399.

15. Zhang J, Feng L, Chen R, Feng T, Dong S. \& Shen H. Levels of polychlorinated biphenyls and organochlorine pesticides in edible shellfish from Xiamen (China) and estimation of human dietary intake. Food and Chem Toxicol. 2012;50:4285-4291.

16. Stancheva M, Georgieva S, Makedonski L. Organochlorine Pollutants in Fish from the Bulgarian Region of the Black Sea. Qual Assur and Safety of Foods and Crops. 2013;5(3):243 - 251.

17. Yu Y, Wang X, Yang D, Lei B, Zhang X, Zhang X. Evaluation of human health risks posed by carcinogenic and non-carcinogenic multiple con- 
taminants associated with consumption of fish from Taihu Lake, China. Food and Chem Toxicol. 2014;69:86-93.

18. NSI (National Statistical Institute), Republic of Bulgaria, Household income, expenditure and consumption during the first quarter of 2010. 2010: Available from: http://www.nsi.bg/EPDOCS/ HBS2010-1q.pdf

19. Georgieva S, Stancheva M, Makedonski L. Organochlorine pesticides and PCBs in marine fish. Ovidius University Annals of Chemistry. 2012;23(1):92-98.

20. Lavandier R, Quinete N, Hauser-Davis RA, Dias PS, Taniguchi S, Montone R, et al. Polychlorinated biphenyls (PCBs) and polybrominated diphenyl ethers (PBDEs) in three fish species from an estuary in the southeastern coast of Brazil. Chemosphere. 2013;90:2435-2443.

21. Bordajandi LR, Martin I, Abad E, Rivera J, Gonzalez MJ. Organochlorine compounds (PCBs, PCDDs and PCDFs) in seafish and seafood from the Spanish Atlantic Southwest Coast. Chemosphere. 2006;64:1450-1457.

22. Isosaari $P$, Hallikainen $A$, Kiviranta $H$, Vuorinen PJ, Parmanne R, Koistinen J, et al. Polychlorinated dibenzo-p-dioxins, dibenzofurans, biphenyls, naphthalenes and polybrominated diphenyl ethers in the edible fish caught from the Baltic Sea and lakes in Finland. Environ Poll. 2006;141:213-225.

23. Szlinder-Richert J, Barska I, Usydus Z, Ruczynska W, Grabic R. Investigation of PCDD/Fs and dl-PCBs in fish from the southern Baltic Sea during the 2002-2006 period. Chemosphere. 2009;74:1509-1515.

24. Kiviranta H, Ovaskainen M, Vartiainen T. Market basket study on dietary intake of PCDD/ Fs, PCBs, and PBDEs in Finland. Environ. Int. 2004;30:923-932.

25. van Leeuwen FX1, Feeley M, Schrenk D, Larsen JC, Farland W, Younes M. Dioxins: WHO's tolerable daily intake (TDI) revisited. Chemosphere. 2000;40(9-11):1095-101.

26. European Commission Scientific Committee on Food. Opinion on the risk assessment of dioxins and dioxin-like PCBs in food. 2001. Available from: http://ec.europa.eu/food/fs/sc/scf/out78_en.pdf.

27. Perello G, Gomez-Catalan J, Castell V, Llobet JM, Domingo JL. Assessment of the temporal trend of the dietary exposure to PCDD/Fs and PCBs in Cat- alonia, Spain: health risks. Food and Chem Toxicol. 2012;50:399-408.

28. Bordajandi LR, Gómez G, Abad E, Rivera J, Fernandez-Baston MM, Blasco J, et al. Survey of persistent organochlorine contaminants (PCBs, PCDD/Fs, and PAHs), heavy metals ( $\mathrm{Cu}, \mathrm{Cd}, \mathrm{Zn}$, $\mathrm{Pb}$, and $\mathrm{Hg}$ ), and arsenic in food samples from Huelva (Spain): levels and health implications. J Agric Food Chem 2004;52:992-1001.

29. Bocio A, Domingo JL, Falcó G, Llobet JM. Concentrations of PCDD/PCDFs and PCBs in fish and seafood from the Catalan (Spain) market: Estimated human intake. Environ Int. 2007;33:170-175. 